\title{
Evaluation of the factors that affect the lignin content in the reed canarygrass (Phalaris arundinacea L.) in Latvia
}

\author{
Liena Poiša ${ }^{1, *}$, Aleksandrs Adamovičs ${ }^{1}$, Rasma Platače $^{2}$, Ėrika Teirumnieka $^{2}$ \\ ${ }^{1}$ Institute of Agrobiotechnology, Latvia University of Agriculture, Jelgava, Latvia \\ ${ }^{2}$ Rezekne Higher Education Institutions, Rezekne, Latvia \\ * Liena Poiša. Tel: +26807673, Fax: +37163005682, E-mail: lienapoisa@inbox.lv
}

\begin{abstract}
In the production of granules from plants the cohesive substance lignin has a great importance, as it holds the granule together and does not allow it to disintegrate. The objective of this research was to evaluate the influencing factors of lignin content in reed canarygrass (Phalaris arundinacea L.) crop yield. In this research the varieties of reed canarygrass 'Marathon' and 'Bamse' were analysed for yields of first and second year. The lignin content of the samples was established by Classon's method. Arsenic (As), Cadmium (Cd), and Lead (Pb) and other chemical elements were established in the reed canarygrass samples with the spectrometer Optima 2100DV. The reed canarygrass second year crop yield was 3-4 times greater than the first year crop yield. A significantly correlation $(\mathrm{p}<0.05)$ was established in the first crop yield October samples between lignin and natrium $(\mathrm{Na})$. Some correlation relationships are contradictory, which confirms that within the plant growth period the meteorological conditions are of great importance. Analysing the determining factors of lignin content it can be seen that they were influenced by the interaction of various factors - the sowing and growing period, the variety and the $\mathrm{N}$-fertilizer rate application.
\end{abstract}

Keywords: Ashes, Heavy Metal, Lignin, N-fertilizer Rate, Phalaris arundinacea L., Yield

\section{Nomenclature}

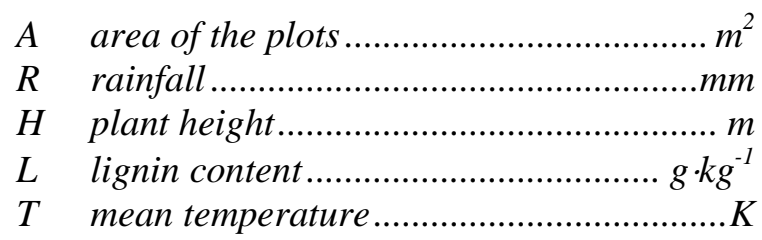

DM dry matter .............................................t $h a^{-1}$

$N \quad$ nitrogen fertilizer rate...................... $\mathrm{kg} \cdot \mathrm{ha}^{-1}$

$\mathrm{Hv}$ heating value................................ $\mathrm{kg}^{-1} \mathrm{DM}$

\section{Introduction}

The most common natural polymer is cellulose, which with lignin and hemicellulose are the main components of plants (Gosselink et al., 2004; Lignin..., 2009). Cellulose pulp is considered as the first depositary of the sun's energy (Gosselink et al., 2004). In nature lignin is very resistant to degradation, as it has strong chemical bonds (McCrady, 1991).

Lignin first appeared hundreds of millions years ago, when plants started to grow vertically upwards. Lignin can be found in all caulescent plants, mainly in the cells and cellwalls. It regulates the transportation of liquid in plant cells (partly strengthening the cell walls, partly regulating the flow of liquid) also it a llows plants to grow longer to better compete for sunlight (McCrady,1991; Rouhi, 2000; Lignin..., 2009).

Lignin which is found in a natural state (protolignin) is of various types, which are common to deciduous trees, conifer trees and stemgrasses. Each type has a lot of variations; lignin can vary with each variety, each plant group, and at the same time even within one cell, and also according to the age of the plant (McCrady, 1991; Zaksis, 2008; Lignin..., 2009).

The technical lignin is used as a bonding material, a surfactant, growth enhancer, a supplementary substance for composite materials and other uses (Skudra et al., 2010). Up to 
now only $2 \%$ of lignin had been used in cellulose and paper production (Gosselink et al., 2004). Products from lignin could be used to replace fossil resources (Gosselink et al., 2004). Also it must be noted, that low lignin content helps animals digest fodder. If the biosynthesis of lignin is complete, then the cell dies (Rouhi, 2000).

Today there are many studies concerning lignin as a by-product of wood-pulp processing. In Latvia it is traditional to produce energy from forestry products, but due to the sharp increase in price for fossil energy, it has become profitable to produce energy from agricultural biomass production. Reed canary grass is suitable for the Latvian agricultural climatic and growth conditions and can be used as a local resource for obtaining renewable energy.

Lignin is used variously, for instance in the production of materials (polymer, glue) and specific chemical substances (concrete additives, emulsifiers, binding materials) (Gosselink et al., 2004). In granule production chemical additives are not desirable (glue, lacquer, etc.) therefore the binding material lignin is important, which holds the granule together and does not allow it to disintegrate. Lignin improves the thermochemical energy transformation effectiveness (Boateng et al., 2006).

The objective of this research: to evaluate the influencing factors of lignin content in reed canarygrass (Phalaris arundinacea L.) crop yield.

\section{Methodology}

\subsection{Field trials}

The object of the research is reed canarygrass (Phalaris arundinacea L.). Three repeat experiments in the field with reed canarygrass varieties 'Marathon' and 'Bamse' were carried out in sod-podzolic loamy soil (the organic content of the soil $-5.2 \%, \mathrm{pH} \mathrm{KCl}-5.8, \mathrm{P}_{2} \mathrm{O}_{5}-20$ $\mathrm{mg} \cdot \mathrm{kg}^{-1}$, and $\mathrm{K}_{2} \mathrm{O}-90 \mathrm{mg} \cdot \mathrm{kg}^{-1}$ of the soil).

The area of the plots was $16 \mathrm{~m}^{2}$, the location of the plots was randomised. The reed canarygrass was sown after bare follow. Before sowing a co mplex fertiliser was applied $\mathrm{N}: \mathrm{P}: \mathrm{K}$ - 5:10:25 - $400 \mathrm{~kg} \cdot \mathrm{ha}^{-1}$. The nitrogen supplementary fertiliser rates: N0 - control, treatments - N30, N60, N90 kg $\cdot \mathrm{ha}^{-1}$. Reed canarygrass variety 'Marathon' was sown on the $12^{\text {th }}$ August in 2008 (henceforth 'Marathon' 08) and varieties 'Marathon' and 'Bamse' - on $29^{\text {th }}$ April in 2009 (henceforth 'Marathon' 09 and 'Bamse' 09). Nitrogen (N) supplementary fertiliser was given to 'Marathon' 08 on the $20^{\text {th }}$ May 2009, and on the $22^{\text {nd }}$ July 2009 for 'Marathon' 09 and 'Bamse' 09. On the $13^{\text {th }}$ April 2010 the reed canarygrass plant growth was renewed. $\mathrm{N}$ fertiliser (ammonium nitrate) was applied at $21^{\text {st }}$ April 2010.

The plant length was determined for five plants on each repeat occasion (for all plant stalks). The reed canarygrass samples were taken on the $12^{\text {th }}$ October 2009 and the $4^{\text {th }}$ April, $7^{\text {th }}$ September, $6^{\text {th }}$ October, $7^{\text {th }}$ November 2010 . The dry matter (DM) samples were taken from $0.25 \mathrm{~m}^{2}$ areas on three occasions on the $12^{\text {th }}$ October 2009 , and the $4^{\text {th }}$ April, $6^{\text {th }}$ October 2010 .

\subsection{Laboratory work}

Arsenic (As), cadmium $(\mathrm{Cd})$, lead $(\mathrm{Pb})$, titanium $(\mathrm{Ti})$, potassium $(\mathrm{K})$, calcium $(\mathrm{Ca})$, magnesium $(\mathrm{Mg})$, sodium $(\mathrm{Na})$ and silicon $(\mathrm{Si})$ concentrations in the reed canarygrass samples were established with the inductively coupled plasma optical emission spectrometer Perkin Elmer Optima 2100 DV. The heating value in the samples was established with the 
calorimeter IKA C 5003. The ash content (three replications) was established with the accelerated standard method. Lignin content (three replications) in samples was determined using the method of Classon (Zaķis, 2008).

\subsection{Meteorological conditions}

The meteorological conditions were different in both trial years (Fig. 1.) The meteorological conditions for agriculture during 2009 the plant growth period had a significant deficit in rainfall. The temperature was in compliance with the long term yearly long-term average. In the winter of 2009/2010 snow was observed to be greater and the temperature was lower than the long term yearly long-term average.

On the $23^{\text {rd }}$ and $24^{\text {th }}$ of April 2010 there was snow and hail. The plant growth period in 2010 was characterized by higher temperatures and a lack of precipitation in April, July, August and September.

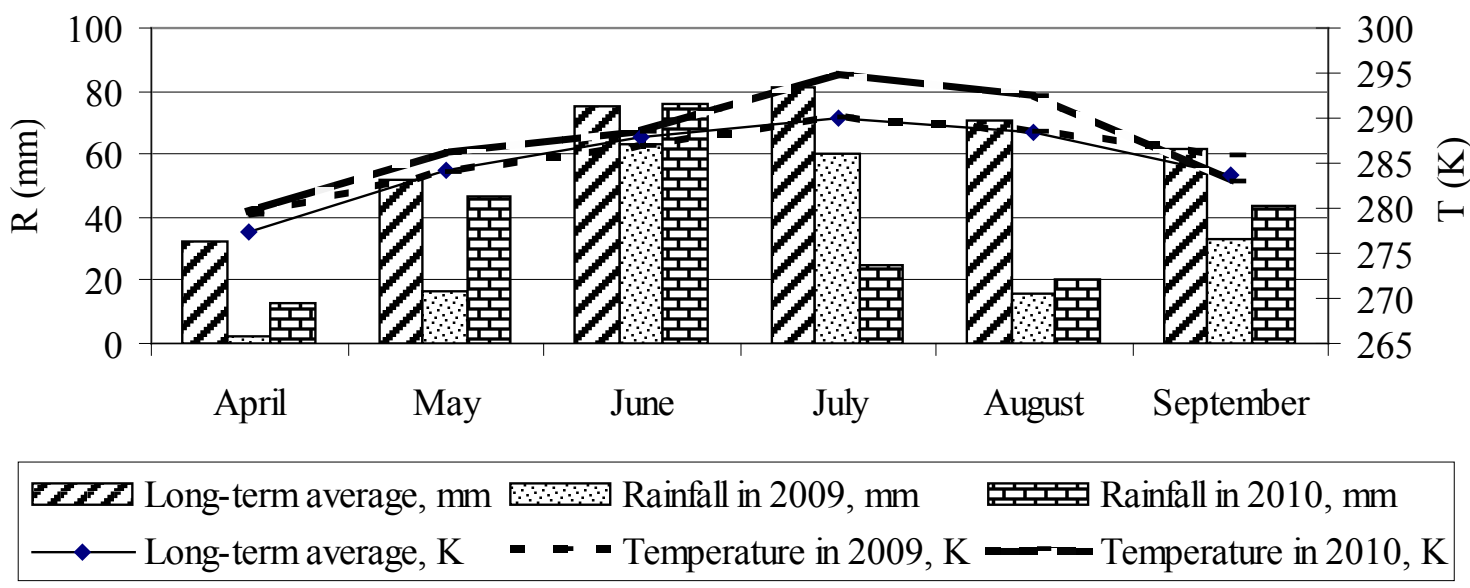

Fig. 1. Mean air temperature and sum of precipitation in 2009 and 2010 growing period.

\subsection{Data analysis}

The trial data were processed using correlation and variance analyses of two and three factors (ANOVA) and descriptive statistics. The means are presented with their LSD test. Representative average samples of the indicators were used in the calculations.

\section{Results}

The reed canary grass varieties sown in 2009 , had a crop yield $3-4$ times greater in the following year compared to the first year crop, but the 2008 sowing only produced a 2 times greater yield (Table 1). Two two-factor variance calculations showed, that the variety 'Marathon' had its crop yield for October 2010 influenced $(\mathrm{p}<0.05)$ by the sowing period $(\eta=62.5 \%)$ and $N$ fertiliser rates $(\eta=19.8 \%)$, but for both varieties 'Marathon' and 'Bamse' a significantly influence $(p<0.05)$ was established for the variety $(\eta=70.7 \%)$ and $N$ fertiliser rates $(\eta=10.8 \%)$. 'Marathon' 09 in the $2010 \mathrm{pl}$ ant growth period grew three times longer compared to the year 2009, which was most influenced by $\mathrm{N}$ fertiliser rates $(\mathrm{p}<0.05)$. 
Table 1. Reed canarygrass dry matter yield and plant length in the second crop year.

\begin{tabular}{|c|c|c|c|c|c|}
\hline $\begin{array}{c}\text { Varieties } \\
\text { Sowing time }\end{array}$ & $\begin{array}{l}\text { Fertilizer } \\
\text { rate } \\
\left(\mathrm{kg} \cdot \mathrm{ha}^{-1}\right)\end{array}$ & $\begin{array}{c}\text { Dry } \\
\text { matter, } \\
\left(\mathrm{t} \cdot \mathrm{ha}^{-1}\right)\end{array}$ & $\begin{array}{l}\text { Increase in } \\
\text { comparison to } \\
\text { the } 2009 \\
\text { October crop } \\
\text { yield }(\%)\end{array}$ & $\begin{array}{l}\text { Increase in } \\
\text { comparison } \\
\text { to the } 2009 \\
\text { April crop } \\
\text { yield (\%) }\end{array}$ & $\begin{array}{c}\text { Plant } \\
\text { height }(\mathrm{m})\end{array}$ \\
\hline 'Bamse' & No & 9.80 & 437 & 456 & 1.548 \\
\hline \multirow[t]{3}{*}{$29^{\text {th }}$ April in 2009} & N30 & 10.25 & 420 & 465 & 1.515 \\
\hline & N60 & 10.27 & 370 & 465 & 1.533 \\
\hline & N90 & 11.79 & 390 & 546 & 1.452 \\
\hline 'Marathon' & No & 8.61 & 424 & 620 & 1.453 \\
\hline \multirow[t]{3}{*}{$29^{\text {th }}$ April in 2009} & N30 & 8.94 & 422 & 493 & 1.566 \\
\hline & N60 & 8.87 & 394 & 406 & 1.527 \\
\hline & N90 & 8.57 & 371 & 384 & 1.485 \\
\hline 'Marathon' & No & 8.98 & 196 & 201 & 1.443 \\
\hline \multirow[t]{3}{*}{$12^{\text {th }}$ August in 2008} & N30 & 10.18 & 218 & 220 & 1.566 \\
\hline & N60 & 10.77 & 227 & 230 & 1.590 \\
\hline & N90 & 10.45 & 216 & 232 & 1.578 \\
\hline $\mathrm{LSD}_{0.05 \text { varieties }}$ & & 0.19 & & & 0.024 \\
\hline $\mathrm{LSD}_{0.05 \text { sowing time }}$ & & 0.18 & & & 0.036 \\
\hline
\end{tabular}

A fundamental correlation $(\mathrm{p}<0.05)$ was established for the samples from the October first year crop between lignin and natrium (Na) (Fig. 2). During the investigation the significantly relationship $(p<0.05)$ between the content of lignin and content of heavy metals in the reed canary grass plants was not established. Revealed a few trends $(\mathrm{p}>0.05)$, when increase lignin content in plants, decreases amount of $\mathrm{Ca}, \mathrm{Cd}$, but the amount of $\mathrm{Si}$ increase in plants. 


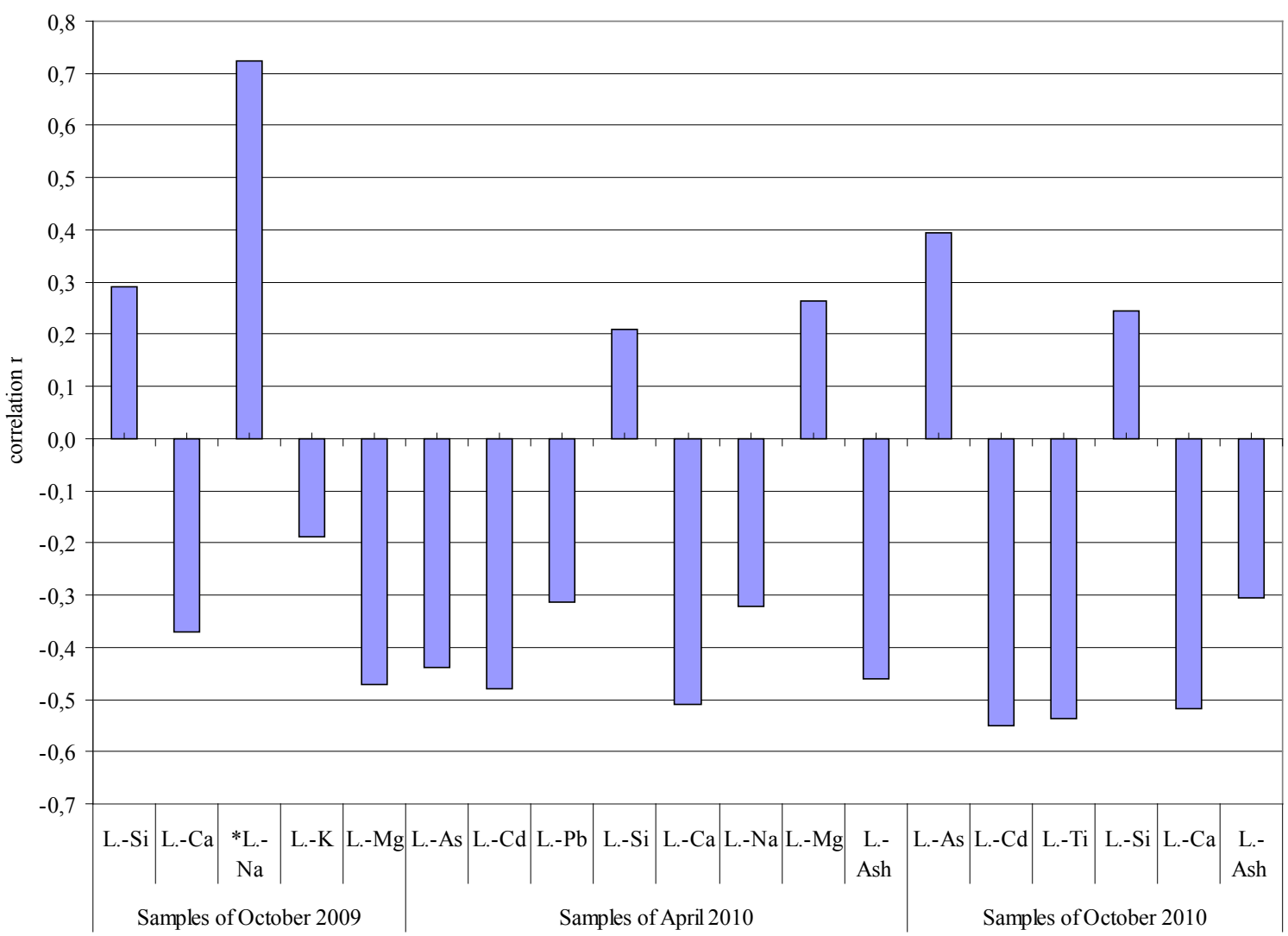

Fig. 2. Relationship between lignin content (L.) and content of the metals in reed canary grass plants: $*(p<0.05)$.

Regression analysis for the samples taken in autumn 2010 shows that between lignin (y) and ash $(x)$ content there is a significant connection $(n=36 ; p=0.0036<0.05)$ which means, that between these indicators there is a linear connection.

The lignin content in the October samples from the $1^{\text {st }}$ year crop yield was $140-210 \mathrm{~g} \cdot \mathrm{kg}^{-1}$, for the April samples it was $200-270 \mathrm{~g} \cdot \mathrm{kg}^{-1}$, but in the $2^{\text {nd }}$ year crop yield it was from 179 $\mathrm{g} \cdot \mathrm{kg}^{-1}$ to $269 \mathrm{~g} \cdot \mathrm{kg}^{-1}$ (Fig. 3). Taking two 3-factor dispersion calculations, it can be seen, that the period when the samples are taken $(\eta=70.1 \%)$ and the amount of the $\mathrm{N}$ fertiliser rate $(\eta=14.7 \%)$ are of significant importance $(p<0.05)$, but the sowing period $(\eta=0.6 \%)$ and the chosen variety $(\eta=3.9 \%)$ have no significant importance. The research has brought up contradictory results; in the 2009 sown varieties had the smallest lignin content using $\mathrm{N}$ fertiliser rate $\mathrm{N} 30 \mathrm{~kg} \cdot \mathrm{ha}^{-1}$, but the lignin content was the largest for the 2008 sown variety 'Marathon', using $\mathrm{N}$ fertiliser rate $\mathrm{N} 30 \mathrm{~kg} \cdot \mathrm{ha}^{-1}$. The polynomial equation shows lignin content depending on the sampling time (Fig. 3). 


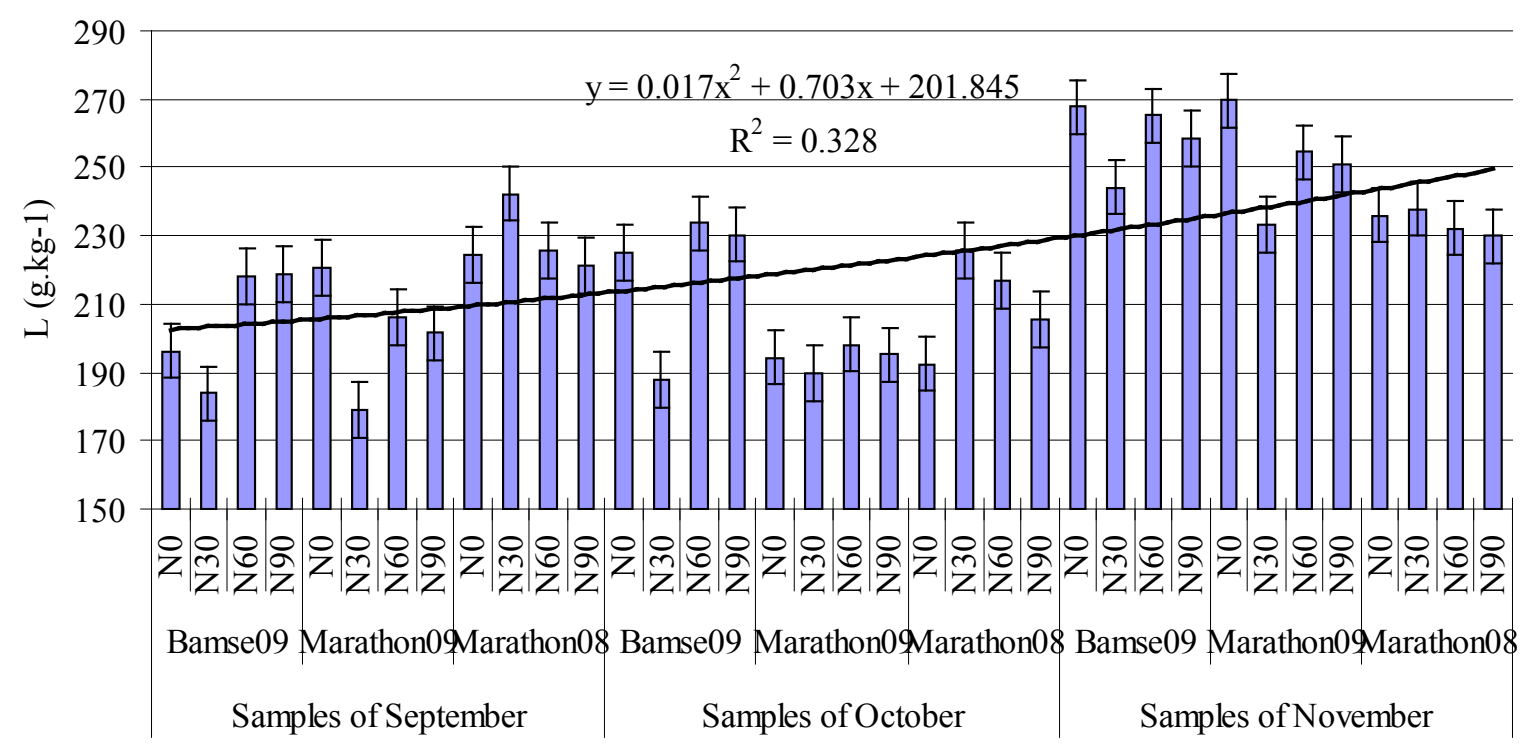

Fig. 3. Lignin content in reed canary grass $2^{\text {nd }}$ year swards in $2010\left(\mathrm{~g} \cdot \mathrm{kg}^{-1}\right)$.

Heating value for the reed canary grass samples for the variable N90 varied from 17.16 to 18.13 MJ $\cdot \mathrm{ha}^{-1} \mathrm{DM}$ (Fig.4). A significant correlation between reed canary grass lignin content and the heating value was not established.

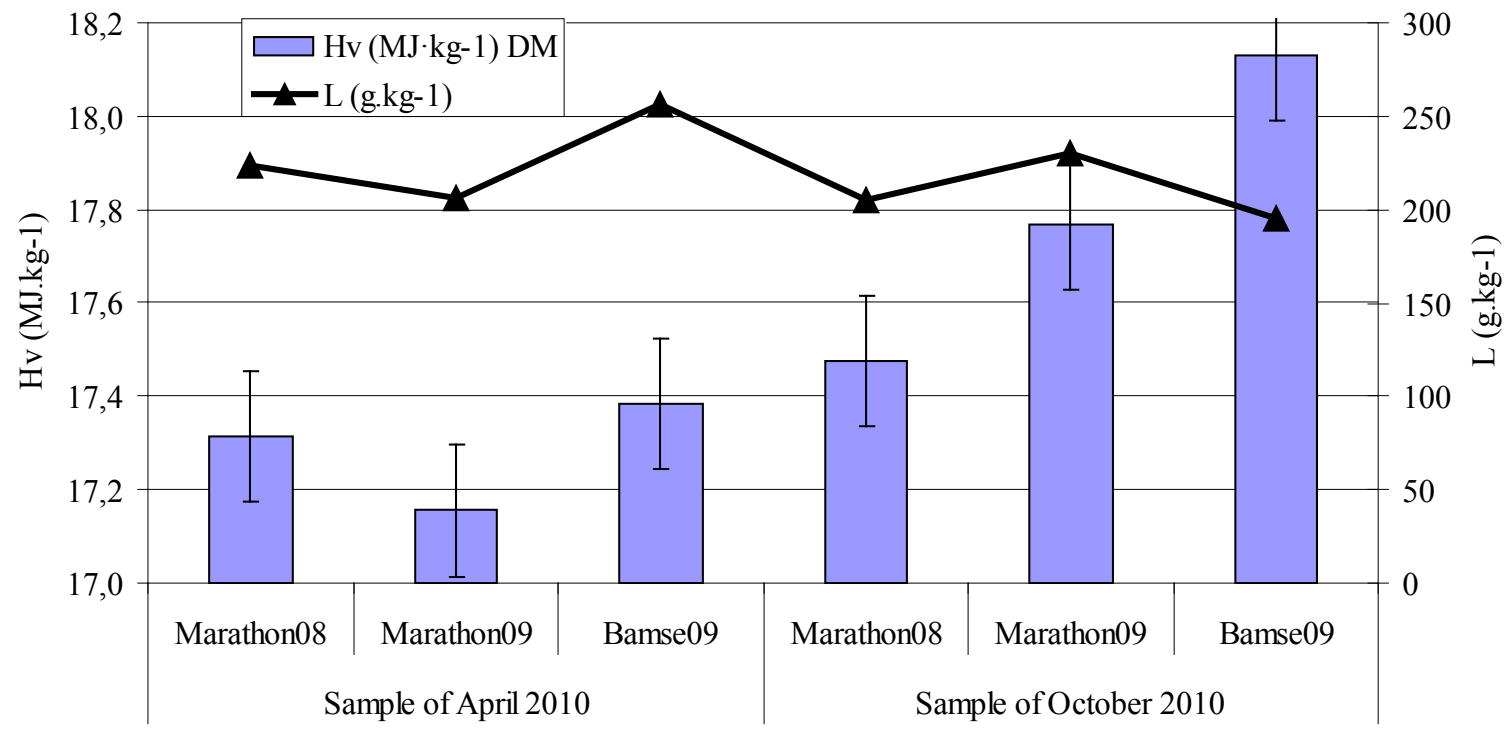

Fig. 4. Reed canary grass sample heating value and lignin content (N $\left.90 \mathrm{~kg} \cdot \mathrm{ha}{ }^{-1}\right)$.

The study will continue, because in this article is only the first and the second year yields lignin content analysis, which can vary when reed canarygrass seed get older, because now there are differences in quality indicators between the first and the second year samples.

\section{Discussion and conclusion}

An extended period with a precipitation deficit and air temperature above the yearly long-term average, get a negative impact on reed canarygrass productiveness during the $2010 \mathrm{pl}$ ant growth period. Comparing lignin content correlations in relationship with various indicators 
for the reed canarygrass crop yield for the $1^{\text {st }}$ year, it can be seen, that for the samples these relationships are not fundamental. Data show, that great importance should be attached to the chemical composition of the plant, which can be manifested also in the genetic characteristics. A few correlative connections are contradictory, which confirms that within the plant growth period the meteorological conditions are of great importance.

Analysing the determining factor of lignin content it can be seen that they were influenced by the interaction of various factors-when the samples were taken, the sowing period, the variety and the $\mathrm{N}$-fertilizer rate application. That is confirmed by other researchers, that the genetic biomass plant background, the period when samples are taken and the growing environment, influence the lignin content in plants (Boateng et al., 2006). The lignin content is significantly influenced by the age of reed canarygrass (McCrady, 1991; Zaķis, 2008; Lignin..., 2009). That means that for lignin extraction reed canary grass harvesting needs to take place as far as possible at the later stages of growth.

In the conclusion of study concluded that on the lignin content in reed canarygrass samples affect the agronomic factors - time of sowing, $\mathrm{N}$ fertilizer rate and harvest time. On the lignin content does not affect amount of heavy metals and other chemicals elements in plants. In study was not found that the lignin content affect on the solid fuel parameters such as ash content and heating value.

\section{Acknowledgements}

This publication has been prepared within the framework of the ESF Project „Attraction of human resources to the research of the renewable energy sources", Contract $\mathrm{Nr}$. 2009/0225/1DP/1.1.1.2.0/09/APIA/VIAA/129. Thanks to Vìtols Fund and the LAB-AN (Latvian Agronomic Society - Foreign Department) for granting me (L. Poiša) a bursary. The authors would like to thank L\&T "Latgales lauksaimniecības zinātnes centrs" for arranging the trials of reed canarygrass; the Rezekne Higher Education Institution of Chemistry Laboratory assistants S. Augule and A. Meinerte for the help with the metal and lignin analysis; the Klaipeda University of Air Pollution from Ships study laboratory for help in determining the heating values.

\section{References}

[1] A. A. Boateng, H. G. Jung, P. R. Adler, Pyrolysis of energy crops including alfalfa stems, reed canarygrass, and eastern gamagrass, Fuel 85, 2006, pp. 2450-2457.

[2] R. J. A. Gosselink, E. de Jong, B. Guran, A. Abächerli, Co-ordination network for lignin - standardisation, production and applications adapted to market requirements (EUROLIGNIN), Industrial Crops and Products 20, 2004, pp. 121-129.

[3] Lignin and Ligninas: Advances in Chemistry, Ed. C.Heitner, D. R. Dimmel, J. A. Schmidt, Taylor and Francis, 2009, 1000 p.

[4] E. McCrady, The Nature of Lignin, Alkaline Paper Advocate 4, 1991, [20 Nov. 2010], http://cool.conservation-us.org/byorg/abbey/ap/ap04/ap04-4/ap04-402.html.

[5] A. M. Rouhi, Lignin and lignan biosynthesis, Chemical \& Engineering News 78, 2000, pp. $29-32$.

[6] S. Skudra, V. Shakels, B. Neiberte, G. Shulga, S. Reihmane, No Kehras celulozes un papīra rūpnīcas "Horizon" melnā atsārma iegūta sulfātlignīna fizikāli ķīmiskais 
raksturojums, RTU zinātniskie raksti 1, Materiālzinātne un lietišķā ķīmija 22, 2010, pp. $38-43$.

[7] G. Zaķis, Koksnes ķīmijas pamati, LV Koksnes ķīmijas institūts, 2008, 199 p. 